\title{
Economy Digitalization: An Experimental Legal Regime
}

\author{
Shamil Arslanov ${ }^{1}{ }^{*}$ Muradgadji Omarov ${ }^{2}$, Viktoriya Stofarandova ${ }^{2}$ \\ ${ }^{1}$ Institute of Social and Economic Research of the Dagestan Federal Research Centre of the RAS, Russia \\ ${ }^{2}$ Dagestan State University, Russia \\ *Email: $\underline{\text { ars_dgu@mail.ru }}$
}

\begin{abstract}
This study aims to determine the directions of the development of digitalization processes in the Russian Federation and identify the features and use of legal mechanisms to stimulate digital innovation elaborations. The paper investigates the main directions of development of the Russian Federation's digital economy considering the analysis of measures provided for by the national project "Digital Economic of the Russian Federation" adopted at the national level. The main legal and organisational mechanisms for the digitalization development of innovations have been determined by analysing the implementation mechanism of an experimental legal regime (ELR). The definitions of its peculiarities for establishing, including the subject composition, rights and obligations. The study results can be applied in the formation and implementation of social and economic policies as a whole and its structural elements separately. Based on the study results, modern trends in the development of digitalization processes are considered, the main approaches of state legal regulation in the field of digital innovations are identified. The ELR development mechanism is analysed, and the specifics of its implementation in the innovations' digitalization are considered.
\end{abstract}

Keywords: Economy, Digitalization, Innovations, Legal regime.

\section{INTRODUCTION}

Most countries consider modern accomplishments in the development of digital technologies as the next stage in developing national economies, allowing them to achieve the necessary economic growth in the face of modern transformations and crises. According to researchers of innovation digitalization processes in various spheres of social activity, such as Van Laar E., Fukuyama M., Krittenden V.F. and Bil I.K. intensive development of modern technologies leads to the transformation of already established markets and the creation of fundamentally new ones. Digitalization as a global phenomenon is acquiring several specific features such as $100 \%$ transformation of traditional business models, changes in the system of scientific research, rendering services of government departments and organisations $[1,2,3]$.

\section{DIGITALIZATION DEVELOPMENT}

As a global trend, digitalization has acquired its form and content in the Russian Federation with the adoption of the national program "Digital Economy of the Russian Federation" [4] as part of the implementation of the Decree of the President of the Russian Federation as of May 7, 2018, No. 204 [5].

According to the national program, the content of the digitalization trend consists of the following six points:

1) normative regulation of the digital environment;

2) human resources for the digital economy;

3) information infrastructure;

4) Information security;

5) digital technologies;

6) digital government management.

On March 2, 2019, a management system for implementing the national program "Digital Economic of 
the Russian Federation" was formed by the Decree of the Government of the Russian Federation No. 234 [6].

Legal regulation of the digitalization process is carried out within the federal project "Normative Regulation of the Digital Environment" [7] and provides for the development and adoption of legislative frameworks to remove the priority barriers hindering the development of the digital economy.

This approach to legal regulation of digital technologies corresponds to the "top-down" concept. That is, first of all, federal laws will be developed and only then is the regional legislation established on their basis, and appropriate by-laws governing procedural issues are adopted. Based on the adopted array of normative legal acts, judicial practice, law enforcement agencies' practice, and the executive branch's practice will begin to be built. In our opinion, the approach used is somewhat conservative. It leads to an unreasonable increase in the number of laws and by-laws adopted at both the federal and regional levels. The process of a snow-balling growth in the number of regulatory documents when applying the "top-down" approach in the regulation of digital innovations cannot be avoided since the digital sphere is very dynamic and rapidly developing.

Today, according to the project "Normative regulation of the digital environment", the critical goal is to create a legal regulation system of the digital economy and the introduction of civil circulation based on digital technologies, 18 federal laws are developed and adopted. Most of which are aimed at removing the priority barriers that impede the development of the digital economy.

In our opinion, it would be more expedient to use the "bottoms up" approach, not excluding the possibility of combining it with the "top-down" approach since there is a relatively large number of issues on the appeals of citizens and organisations that have already been considered by courts and law enforcement agencies. Practical recommendations and the existing judicial and administrative practice experience will allow avoiding a possible low-quality legal regulation. A similar mechanism is the development of a new legal regime in the so-called "sandbox".

The approach offered by us is reflected in the Federal Law as of July 31, 2020. No. 258-FZ "On Experimental Legal Regimes in the Field of Digital Innovations in the Russian Federation" [8], which will come into force on January 28, 2021. It will allow persons involved in the development and implementation of digital innovations to carry out their practical application and approbation of their usefulness in the absence of restrictions and other encumbrances established by regulatory legal acts without the risk of violating them.

\section{DIGITALIZATION AND ELR}

An experimental legal regime (ELR) implies special (different from the general) regulation to its participants for a certain time, simplifying the implementation of digital innovations. Moreover, such a regime can be created only in certain areas, named in the investigated Federal Law (FZ) and those determined by the Russian Federation Government.

In our opinion, the ELR mechanism's introduction is necessary due to the static nature of law in innovations. The growing need to develop legal regulation in digital innovations has led to the ELR law's adoption. Dostov V.L., Gromova E.A., Achilova, M.A., Efremov A.E and other researchers adhere to the same opinion $[9,10,11,12]$.

To date, according to the Federal Law, the ELR can be established only under strict observance of the following conditions: [13]

1) the general legal regulation does not provide an opportunity to develop digital innovations;

2) availability of a technical capability to develop digital innovations;

3) using the ELR will lead to the achievement of one or several objectives of the Federal Law;

4) availability of a comprehensive assessment of all possible risks and the development of measures to minimise them.

The fundamental advantage of the ELR Federal Law is its versatility, which allows it to be applied not only in the technical field. Simultaneously, its versatility leads to the need to bring the definitions to a single understanding, which is directly related to the identity of the terms used in the Federal Law "On Science and State Scientific and Technical Policy" as of August 23, 1996. No. 127-FZ [14].

The existing inaccuracies and discrepancies in both laws' terminological base may cause difficulties in determining the ELR object in the near future.

Simultaneously, there is a need to resolve issues and problems related to innovations that do not fall under their normatively fixed definition of "digital innovations".

According to the law, the ELR can be introduced only concerning a set circle of ELR subjects or one specific ELR subject for a certain period. Regardless of regional specifics, there is a three-year deadline for establishing the ELR with the possibility of extending it for a year.

The rights and legitimate interests of the ELR subject are guaranteed by the impossibility of changing and terminating the ELR, except: 
1) the entry into force of another Federal Law;

2) decisions of the Russian Federation Government;

3 ) in other cases, provided by the ELR program.

It should also be noted here that the ELR is introduced. Its legal regulation is carried out by authorised federal state bodies and state authorities of the Russian Federation's constituent entity.

In our opinion, the municipal level's exclusion from the ELR regulation system will lead to the formation of various kinds of barriers and inconsistencies at the municipal level. It would be more logical to empower the municipal authorities with the opportunity to participate in the ELR regulation.

The ELR and an assessment of its effectiveness and efficiency are monitored by the authorised body, the regulatory body, and the business community's organisation based on reports of the ELR subjects on the activities' results within implementing the such an ELR.

Based on the results of the ELR monitoring as well as assessing the effectiveness and efficiency of its implementation, the summary analytical report sets out the conclusions of the authorised body, regulatory body and organisation of the business community, which contain the following information: [15]

1) on the admissibility of giving the general regulation property to the special regulation;

2) on the admissibility of giving the general regulation property to the special regulation in case of amendments to the special regulation;

3) on the inadmissibility of giving the general regulation property to special regulation.

It seems logical that an organisation's inclusion for protecting consumer rights in the considered list of organisations performing ELR monitoring and effectiveness.

Such a measure will ensure the necessary protection level of potential consumers' interests in innovative activities results carried out within the experimental legal regime framework.

This measure is not an innovation in the world practice and has many examples. For instance, in Singapore, the decision to apply the regulatory sandbox regime is made by authorised bodies in consultation with public organisations in society's interests in general, not its individual layers.

The ELR Law explicitly states that the ELR subject must inform a person expressing the intention to enter a legal relationship with the ELR subject as part of the ELR implementation about the ELR presence and content. The entry of a person into legal relations with the ELR subject within the ELR implementation framework after informing him/her means the consent of this person to applying special regulation to the specified legal concerns and recognition of him/her as a participant of the ELR. If the activities carried out within the ELR implementation framework may affect the rights and legitimate interests of persons who do not enter legal relations with the ELR subject. Within the framework of the implementation of such an ELR, the specified ELR subject before the start of the ELR validity period, as well as when performing transactions under the ELR program, concluding contracts, sending legally important messages and performing other legally significant actions is obliged to notify persons who are not participants of such an ELR about his/her status as an ELR subject, and indicate that special regulation acts are applied to $\mathrm{him} / \mathrm{her}$, at the same time it is necessary to apply the relevant information on goods produced under an ELR, place it in front of the entrances (passages) to the territory of the ELR, in front of the entrances to the premises in which the works are performed, services are rendered within the specified ELR. The ELR program determines the need for additional publication and placement of such information and its requirements.

Suppose these legally significant actions are performed using the information and telecommunication network "Internet". In that case, the ELR subject is obliged to inform the user (transaction party) about all applicable provisions of special regulation acts that differ from general regulation acts.

Another significant omission of the ELR Law is the absence of a prescribed condition to obtain clients' prior consent or counterparties on interaction with an entity concerning whose activities the ELR has been introduced.

Such a condition is mandatory to be included in the required regulations on regulatory sandboxes in countries such as Singapore, Australia and the UK. In our opinion, such a measure will allow us to reduce possible risks associated with testing and implementing digital innovations.

\section{CONCLUSIONS AND RESULTS}

Modern trends in digitalization of the Russian Federation's economy have a conservative orientation, expressed in keeping the "top-down" approach when forming the organisational and legal mechanisms for regulating digital innovations. This will undoubtedly lead to a significant increase in the number of laws and bylaws adopted at both the federal and regional levels since the digital sphere is very dynamic and rapidly developing.

Already, today, according to the project "Normative regulation of the digital environment", the fundamental goal of which is to create a system of legal regulation of the digital economy, as well as the introduction of civil 
circulation based on digital technologies, we have eighteen developed and adopted federal laws. The feasibility of which is justified by the need to remove the priority barriers that impede the digital economy's development.

In the legal regulation of digital innovations, It is necessary to apply the "bottom-up" approach in combination with the "top-down" approach, which, in our opinion, will make it possible to use the existing developments in the regulation of legal relations in the field of digital technologies development. An example of this approach is developing an experimental legal regime in the so-called "sandbox".

However, today even the use of working out in the "sandbox" raises several questions concerning the determination of significant differences between the ELR and legal experiment and, consequently, determining the possibilities of choosing one or another mechanism under specifically established conditions.

Establishing an ELR, in our opinion, can be advisable only in the case when a legal experiment is not able to ensure the development or creation of digital innovations on time. As a rule, legal experiments in the field of innovations have already been applied in our country, for example:

$\checkmark$ from July 1, 2019 to March 31, 2020, based on a legal experiment, a project was implemented to improve the quality and coherence of data contained in state information resources;

$\checkmark$ From August 30, 2019 to December 30, 2020, a project was implemented to transfer the federal executive authorities' information systems to the state unified cloud platform based on a legal experiment.

It is also necessary to consider in more detail the issues of assessing ELR effectiveness and efficiency. Such an assessment of efficiency and effectiveness should, in our opinion, be carried out not after the completion of the ELR but during the decision to introduce it (preliminary assessment) and during its implementation (current assessment). Simultaneously, it should be emphasised that the main goal for introducing the ELR should be an opportunity to test innovations in the digital sphere to form a mechanism for their early application. And due to a significant reduction in the time interval between the development and implementation of digital innovation, it will make it possible to reduce developers' costs and test the economics of its operation and create an additional opportunity to abandon the "non-working" model.

\section{REFERENCES}

[1] Van Laar E. et al., 21st century digital skills instrument aimed at working professionals: Conceptual development and empirical validation,
Telematics and informatics Vol. 35 Iss. 8 (2018) 2184-2200E.

[2] M. Fukuyama, Society 5.0: Aiming for a new human-centred society, Japan Spotlight Vol. 1 (2018) 47-50.

[3] W.F. Crittenden, I.K. Biel, W.A. Lovely III, Embracing digitalization: student learning and new technologies, Journal of Marketing Education Vol. 41 Iss. 1 (2019) 5-14.

[4] "Digital Economy of the Russian Federation" Ministry for Digital Development, Communications and Mass Media of the Russian Federation [Electronic resource]. Retrieved from: https://digital.gov.ru/ru/ (reference date is 21.11.2020)

[5] Decree of the President of the Russian Federation dated May 7, 2018, No. 204 "On national goals and strategic objectives of the development of the Russian Federation for the period until 2024" [Electronic resource]. Retrieved from: http://www.kremlin.ru/acts/bank/43027 (reference date is 21.11.2020)

[6] Decree of the Russian Federation Government as of March 2, 2019, No. 234 "On the management system for the implementation of the national program "Digital Economy of the Russian Federation" [Electronic resource]. Retrieved from: https://www.garant.ru/products/ipo/prime/doc/720 90034/ (reference date is 21.11.2020).

[7] Normative regulation of the digital environment, Ministry for Digital Development, Communications and Mass Media of the Russian Federation [Electronic resource]. Retrieved from: https://digital.gov.ru/ru/ (reference date is 21.11.2020)

[8] Federal Law as of July 31, 2020, No. 258-FZ "On experimental legal regimes in the field of digital innovations in the Russian Federation" [Electronic resource]. Retrieved from: http://www.consultant.ru/document/cons_doc_LA W_358738/ (reference date is 21.11.2020).

[9] V.L. Dostov, Institute of "regulatory sandboxes" as a tool to support financial innovations, V.L. Dostov, P.M. Shust, E.S. Ryabkova, Money and credit 10 (2016) 51-56.

[10] E.A. Gromova, On the issue of experimental legal regimes for creating digital innovations (regulatory sandboxes), Bulletin of South Ural State University. Series: Law, Iss. 3, 2019 [Electronic resource]. Retrieved from: https://cyberleninka.ru/article/n/kvoprosu-ob-eksperimentalnyh-pravovyh-rezhimah- 
sozdaniya-tsifrovyh-innovatsiy-regulyatornyhpesochnitsah

[11] M.A. Achilova, Financial technologies and the prospects for developing the institution of "regulatory sandboxes" in the Russian Federation, M.A. Achilova, Materials of the X International Scientific and Practical Conference "Innovative Development of the Russian Economy", The Plekhanov Russian University of Economics, Yekaterinburg, 2017, p. 346367.

[12] A.E. Efremov, The directions for improving legal regulation in the sphere of stimulating the development of information technologies, A.E. Efremov, V.N. Yuzhakov, Russian Law, Education. Practice. Science 5 (2017) 62-69.

[13] Experimental legal regimes Ministry of Economic Development of the Russian Federation [Electronic resource]. Retrieved from: https://www.economy.gov.ru/ (reference date is 21.11.2020)

[14] Federal Law "On Science and State Scientific and Technical Policy" dated August 23, No. 127-FZ, 1996 [Electronic resource]. Retrieved from: http://www.consultant.ru/document/cons doc LA W_11507/ (reference date is 21.11.2020)

[15] Experimental legal regimes in the field of digital innovations in Russia [Electronic resource]. Retrieved from: https://www.tadviser.ru/ (reference date is 21.11.2020) 